Ann. Biol. anim. Bioch. Biophys., I970, 10 (I), 5I-58.

\title{
SIRE SPECIFICITY OF MOVEMENT CHARACTERISTICS AND LONGEVITY OF BULL SPERMATOZOA
}

\author{
C. VAN DUIJN, Jr., H.W. VERVER \\ Departments of Biophysics and of Mathematical Statistics, \\ Research Institute for A nimal Husbandry "schoonoord", \\ Driebergseweg $10 \mathrm{~d}, Z$ eist, the Netherlands
}

\section{SUMMARY}

Bull specificity of initial mean velocity and number of normally moving spermatozoa per unit volume, and the rates of decrease of numbers and velocity with time has been investigated in three pairs of monozygous twins of Dutch-Friesian breed.

By means of an analysis of variance positive results were obtained for the numbers of normally moving spermatozoa per unit volume, $N_{0}$, initial migration rates $(N \cdot \bar{v})_{0}$, for the half-life periods of these characteristics, $t_{1 / 2}(N)$ and $t_{1 / 2}(N \cdot \bar{v})$ and for the fertility criteria $t_{1 / 2}(N) \cdot \log N_{0}$ and $t_{1 / 2}(N \cdot \bar{v}) \cdot \log (N \cdot \bar{v})_{0}$, but not for the initial velocity $\bar{v}_{0}$ and the rate of velocity decrease with time, $-\partial \bar{v} / \partial t$.

\section{INTRODUCTION}

In previous investigations on movement and longevity of bull spermatozoa by means of photo-electric methods no sire-specificity could be proven, although there was a suggestion that at least the half-life periods of numbers of normally moving sperms might be bull-specific (RIKMENSPOEL, I957 b, van DUIJN, I962). The present study is an evaluation of more extensive data, obtained with a more accurate measuring system.

\section{MATERIAL, AND METHODS}

Bull specificity was studied in three pairs of monozygous twins of Dutch-Friesian breed, sampled systematically during the same two-years period.

Twin bulls were used for facilitating distinguishing between environmental factors and genetically determined characters; otherwise a much more extensive herd of experimental animals would have been required. 
All bulls were of the same age, being 6 years in the middle of the experimental period.

Variation between months of sampling exceeds total bull variation within the same month on the average by a factor of $2-3.5$, depending on the parameter studied. Since in the present investigation we were not interested in seasonal variation and the whole procedure could be simpler by eliminating this source of variance first, the data were normalised prior to the analysis of variance.

Seasonal variation was compensated by normalising all data relative to the geometric means of the parameter values obtained over all bulls in the herd that had been sampled during the corresponding periods (van DUIJN; $\mathrm{I}_{96} b, \mathrm{I} 96_{5} a, b$ ).

The geometric means is obtained by averaging over the logarithms of the parameter values and taking the anti-logarithm of the result. The elimination of the seasonal effect was obtained by dividing every individual parameter value of an ejaculate by the corresponding geometric means of the parameter values of the comparison population of bulls.

The representative mean values are the geometric rather than the arithmetic means, because it has been shown that all parameters studied follow a logarithmic frequency distribution (van DuIJn, 1962, 1963, $1964 e, 1965 b$ ).

The absolute values are not of interest in this context, owing to the much larger scatter due to seasonal variation than to bull differences within each month as just mentioned. However, it may be stated for general information that all measured data were within the ranges obtained in previous investigations ( $\operatorname{van}$ DUIJN I962, I964 $b, \mathrm{Ig} 65 b$ ).

The analysis was performed step-by-step, $i, e$. starting with one or two parameters at a time as soon as these data had been calculated and tabulated. Accordingly, new data accumulated constantly during the processing period, which is the reason that the numbers of degrees of freedom increased from 136 in the data processed first, up to I 54 in the series that was processed last. Obviously it did not make sense to repeat an analysis after addition of some more data where significance had already been reached.

Fresh ejaculates were diluted in two steps with standard ultramicroscopically clear eggyolk-citrate buffer medium (RIKMENSPOEL, I957 $a$ ) and the mean velocities and numbers of spermatozoa were determined from the recordings obtained with Rikmenspoel's (I957 $b$, I960) photo-electric method, as described previously (van Duijn, I962).

Measuring accuracy was improved by measuring three samples from each diluted ejaculate on the day of ejaculation, and another three after 24 hours storage in a Dewar vessel with ice at $1.9 \pm \mathrm{I} .2$ (S D.) ${ }^{\circ} \mathrm{C}$. From the regressions $\log N=f(t)$ and $\log (N \cdot \bar{v})=f(t)$ the initial values $N_{0}$ and $(N \cdot \bar{v})_{0}$ at the moment of ejaculation were obtained, as well as the parameters of survival $t_{1 / 2}(N)=$ half-life period of numbers of normally moving sperms, and $t_{1 / 2}(N \cdot \bar{v})=$ half-life period of migration rate, the latter being defined as the product of numbers per unit volume and their mean velocity $\vec{v}$. The product $N \cdot \bar{v}$ is proportional to the number of spermatozoa passing by a fixed spot in the field of a microchamber per unit time and is obtained directly from the count of the recorded specimens, whereas $N$ is obtained by dividing this value by the mean velocity $\bar{v}$.

\section{COMPARISON BETWEEN SIRES}

No significant differences could be obtained between sires with respect to the initial velocity $\bar{v}_{0}$ and to the rate of decrease of velocity with time, $-\partial \bar{v} / \partial t$. Initial numbers of normally moving spermatozoa per unit volume, $N_{0}$, were found significantly different between pairs $(0.05>\mathrm{P})$ (twin pair specificity). The differences between the partners of each pair were not significantly less than the differences between unrelated animals. Table 2 shows the summarised data of the analysis of variance (table I).

The initial value of the migration rate, $(N \cdot \bar{v})_{0}$, was also different between pairs $(0.05>\mathrm{P})$ and the partners of each pair did not differ less than unrelated animals (table 2).

The half-life period of the numbers of normally moving spermatozoa, $t_{1 / 2}(N)$, and of the migration rates, $t_{1 / 2}(N \cdot \bar{v})$, differed significantly between pairs, with 0.OI $>\mathrm{P}$ for $t_{1 / 2}(N)$ and $0.05>\mathrm{P}$ for $t_{1 / 2}(N \cdot \bar{v})$, respectively. The partners of each twin did not differ significantly less from each other than unrelated animals (tables, 3-4) 


\section{TABLE I}

Analysis of variance of initial numbers of normally moving spermatozoa $N_{0}$ per unit volume in three pairs of monozygous bull twins

Analyse de variance du nombre initial de spermatozoïdes se déplaçant normalement, $N_{0}$ par unité de volume chez trois paives de taureaux jumeaux homozygotes

\begin{tabular}{c|c|c|c|c}
\hline Source of variation & $\begin{array}{c}\text { Sum of } \\
\text { squares }\end{array}$ & $\begin{array}{c}\text { Degrees of } \\
\text { freedom }\end{array}$ & $\begin{array}{c}\text { Mean } \\
\text { square }\end{array}$ \\
\hline Differences between pairs ... & 2.0522 & 2 & 1.0261 & $F_{136}^{3}=\frac{0.3180}{0.2230}=1.47$ N. S. \\
Differences within pairs .... & 0.9539 & 3 & 0.3180 & $F_{136}^{2}=\frac{1.0261}{0.2230}=4.60^{*}$ \\
Differences within bulls .... & 30.3245 & 136 & 0.2230 & $F_{3}^{2}=\frac{1.0261}{0.3180}=3.23 \mathrm{~N}$. S. \\
\hline
\end{tabular}

* $\mathrm{P}<0.05$

TABLE 2

Analysis of variance of initial migration rates of normally moving spermatozoa, $(N \cdot v)_{0}$ in three pairs of monozygous bull twins

Analyse de variance des rapidités de déplacement initiales des spermatozoïdes se déplaçant normalement, $(N \bar{v})_{0}$ chez trois paires de taureaux jumeaux homozygotes

\begin{tabular}{|c|c|c|c|c|c|}
\hline Source of variation & $\begin{array}{l}\text { Sum of } \\
\text { squares }\end{array}$ & $\begin{array}{c}\text { Degrees of } \\
\text { freedom }\end{array}$ & $\begin{array}{l}\text { Mean } \\
\text { square }\end{array}$ & & \\
\hline Differences between pairs & $2: 20 \div 2$ & $\ddot{z}$ & 1.1011 & $F_{146}^{3}=$ & $\frac{0.2597}{0.2695}=0.96$ N.S. \\
\hline Differences within pairs & 0.7791 & 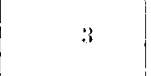 & 0.2597 & $F_{146}^{2}=$ & $\frac{1.1011}{0.2695}=4.09^{*}$ \\
\hline Differences within bulls & $39.310=$ & 196 & 0.2695 & $\mathrm{~F}_{3}^{2}=$ & $\frac{1.1011}{0.2597}=4.24$ N.S. \\
\hline
\end{tabular}

$* \mathrm{P}<0.05$ 
TABLE 3

Analysis of variance of the half-life period of numbers of normally moving spermatozoa $t_{1 / 2}(N)$ in three pairs of monozygous bull twins

Analyse de variance de la période de demi-valeur des spermatozoïdes se déplaçant normalement $t_{1 / 2}(N)$ chez trois paires de taureaux jumeaux homozygotes

\begin{tabular}{|c|c|c|c|c|c|}
\hline Source of variation & $\begin{array}{l}\text { Sum of } \\
\text { squares }\end{array}$ & $\begin{array}{c}\text { Degrees of } \\
\text { freedom }\end{array}$ & $\begin{array}{c}\text { Mean } \\
\text { square }\end{array}$ & & \\
\hline Differences between pairs... & 3.457 & 2 & 1.729 & $F_{154}^{3}=$ & $\frac{0.295}{0.308}=0.96 \mathrm{~N} . \mathrm{S}$. \\
\hline Differences within pairs .... & $0.884_{4}$ & 3 & 0.295 & $\mathrm{~F}_{154}^{2}=$ & $\frac{1.729}{0.308}=5.61_{\mathrm{t}}^{\prime *}$ \\
\hline Differences within bulls .... & 47.476 & $15 \mathbf{t}^{\prime}$ & 0.308 & $\mathrm{~F}_{3}^{2}=$ & $\frac{1.729}{0.295}=5.861$ N.S. \\
\hline
\end{tabular}

$P<0.01$

TABLE 4

Analysis of variance of the half-life period of migration rate of normally moving spermatozoa $t_{1 / 2}(N \cdot \bar{v})$ in three pairs of monozygous bull twins

Analyse de variance de la période de demi-valeur pour la rapidité de déplacement des spermatozoĩdes se déplaçant normalement $t_{1 / 2}(N \cdot \bar{v})$ chez trois paives de taureaux jumeaux homozygotes

\begin{tabular}{|c|c|c|c|c|c|}
\hline Source of variation & $\begin{array}{l}\text { Sum of } \\
\text { squares }\end{array}$ & $\begin{array}{c}\text { Degrees of } \\
\text { freedom }\end{array}$ & $\begin{array}{c}\text { Mean } \\
\text { square }\end{array}$ & & \\
\hline Differences between pairs ... & 2.5373 & 2 & 1.2686 & $\mathrm{~F}_{150}^{3}=$ & $\frac{0.1945}{0.3233}=0.60$ N.S. \\
\hline Differences within pairs .... & 0.5835 & 3 & 0.1945 & $\mathrm{~F}_{150}^{2}=$ & $\frac{1.2686}{0.3233}=3.92 *$ \\
\hline Differences within bulls $\ldots$. & 48.4968 & 150 & 0.3233 & $\wedge F_{3}^{2}=$ & $\frac{1.2686}{0.19 \pm 5}=6.52$ N.S. \\
\hline
\end{tabular}

* $\mathrm{P}<0.05$ 


\section{TABLE 5}

Analysis of variance of the fertility criterion $t_{1 / 2}(N \cdot \bar{v}) \cdot \log (N \cdot \bar{v})$ in three pairs of monozygous bull twins

Analyse de variance du critère de fertilité $t_{1 / 2}(N \cdot \bar{v}) \cdot \log (N \cdot \bar{v})$ chez trois paires de taureaux jumeaux homozygotes

\begin{tabular}{c|c|c|c|c}
\hline Source of variation & $\begin{array}{c}\text { Sum of } \\
\text { squares }\end{array}$ & $\begin{array}{c}\text { Degrees of } \\
\text { freedom }\end{array}$ & $\begin{array}{c}\text { Mean } \\
\text { square }\end{array}$ \\
\hline Differences between pairs ... & 4.358 & 2 & 2.179 & $\mathrm{~F}_{150}^{3}=\frac{0.176}{0.417}=0.42$ N. S. \\
Differences within pairs .... & 0.527 & 3 & 0.176 & $\mathrm{~F}_{150}^{2}=\frac{2.179}{0.417}=5.23 *$ \\
Differences within bulls .... & 6.2 .566 & 150 & 0.417 & $\mathrm{~F}_{3}^{2}=\frac{2.179}{0.17} \frac{17}{6}=12.38 *$
\end{tabular}

$* \mathrm{P}<0.05$

TABI_E 6

Analysis of variance of the fertility criterion $t_{1]_{2}}(N) \cdot \log N$, in three pairs of monozygous bull twins

Analyse de variance du critère de fertilité $t_{1 / 2}(N) \cdot \log N$ chez trois paires de taureaux jumeaux homozygotes

\begin{tabular}{|c|c|c|c|c|c|}
\hline Source of variation & $\begin{array}{l}\text { Sum of } \\
\text { squares }\end{array}$ & $\begin{array}{c}\text { Degrees of } \\
\text { freedom }\end{array}$ & $\begin{array}{l}\text { Mean } \\
\text { square }\end{array}$ & & \\
\hline Differences between pairs ... & 4.7806 & $\underline{z}$ & 2.3903 & $\mathrm{~F}_{13 B}^{3}=$ & $\frac{0.5468}{0.3681}=1.49$ N.S. \\
\hline Differences within pairs. & $1.6+05$ & 3 & 0.5468 & $\mathrm{~F}_{136}^{\mathrm{3}}=$ & $\frac{2.3903}{0.3681}=6.49 * *$ \\
\hline Differences within bulls .... & 50.056 & 136 & 0.3681 & $\mathrm{~F}_{3}^{2}=$ & $\frac{2.3903}{0.5468}=4.37$ N.S. \\
\hline
\end{tabular}

** $\mathrm{P}<0.01$ 
The complete fertility criterion $t_{1 / 2}(N \cdot v) \cdot \log (N \cdot \bar{v})_{0}$ was significantly different between pairs $(0.05>\mathrm{P})$, whereas the partners of each pair were significantly more resembling each others performance than unrelated animals (table 5).

With respect to the simpler fertility criterion $t_{1 / 2}(N) \cdot \log N_{0}$ there was even greater significance of the difference between pairs (O.OI $>\mathrm{P}$ ), but no less difference between the performance of the partners of each twin pair and unrelated sires (table 6 ).

\section{DISCUSSION}

The absence of demonstrable differences between monozygous twin sires of the same breed with respect to the initial mean velocity $\bar{v}_{0}$ and the rate of velocity decrease with time, - - $\partial \bar{v} / \partial t$, strenghthens the previous conclusion that initial swimming velocity of spermatozoa is in itself no useful characteristic for semen evaluation (van DuIJN, I962, I964a, b), derived from the correlation between rapid deterioration and high initial velocity : Corr. $-\partial \bar{v} / \partial t \times \bar{v}_{0}=0,85, \mathrm{P}<\mathrm{IO}^{-12}$; Corr. $\log$. $(-\partial v / \partial t) \times \log t_{1 / 2}(N): r=-0.85, \mathrm{P}<0.001 ; \operatorname{Corr} \log (-\hat{c} v / \partial t) \times \log t_{1 / 2}$ $(N \cdot \bar{v}): r=-0.88, P<0.000$ I (van DuijN, I965 b).

The only significant single parameters are $t_{1 / 2}(N)$ and $t_{1 / 2}(N \cdot \bar{v})$ There is a strong correlation between these two, which is linear in the logarithmic form : Corr. $\log \left(t_{1 / 2}(N)\right) \times \log \left(t_{1 / 2}(N \cdot \bar{v})\right): r=0.982$ with I74 degrees of freedom $\left(\mathrm{P}<\mathrm{IO}^{-12}\right)$ (van DurjN, I963, Ig64 a).

Since the product $N \cdot \bar{v}$ is proportional to the number of sperms passing by a fixed spot in the field of observation per unit time, it can be determined easier and more rapidly than $N$ and $\bar{v}$ separately. Consequently, $t_{1 / 2}(N \cdot \bar{v})$ has definite advantages over $t_{1 / 2}(N)$ as a characteristic parameter for longevity of spermatozoa.

RIKMENSPOEL, (I957 b, I960) suggested that the half-life periods of normally moving spermatozoa would probably be bull-specific. About the same material, including four bulls with $2-4$ ejaculates each, he stated later on that: "The half-life for the decrease in the number of moving cells shows a definite individual specificity for each bull "(RIKMENSPOEL, I962), but this conclusion is not warranted by the data, because the four bulls belonged to different breeds (FH and MRY) and had not been sampled at the same time, so that differences could also be due to seasonal variations. Later investigations (van DUIJN, I962), including 43 ejaculates from I6 bulls, also sampled randomly, were inconclusive too.

Only with systematic sampling of monozygous twin bulls of one single breed over a longer period and correcting for seasonal fluctuation as well as accounting for the skewness of the frequency distributions could in the present study bullspecificity of $t_{1 / 2}(N)$ for the first time be demonstrated with statistical significance.

As to be expected from the high correlation, the mean level of $t_{1 / 2}(N \cdot v)$ comes out to be bull specific, too.

With respect to the initial number of normally moving spermatozoa per unit volume $N_{0}$ and the initial migration rate $(N \cdot \bar{v})_{0}$ it is suggested that there could be a genetic difference in potential level of spermatozoan output between sires.

Again, there is a strong correlation between $N$ and $N \cdot \bar{v}$ (determined at the same time), which is straight in the logarithmic form (van DUIJN, Ig63, I964a) with $r=0,93$ 
and 620 degrees of freedom over randomly sampled ejaculates. This correlation is even greater if it is calculated over ejaculates collected in the same month, owing to the fact that the mean velocity $v$ varies considerably between months, but much less within months. This confirms the usefulness of passage counting (proportional with $N \cdot \bar{v}$ ) to estimate $N$ (van DAm, I958; van DurJN, I964 $a, d$ ).

Neither the initial values of $N$ and $N \cdot \bar{v}$ nor their half-life periods follow the same course as fertility over the whole year, but the kinetic fertility criteria $t_{1 / 2}(N \cdot \bar{v})$. $\log (N \cdot v)_{0}$, and $t_{1 / 2}(N) \cdot \log N_{0}$ show good agreement (van DuiJN, I964 $\left.b, 1965 a, b\right)$. Results of the present investigation revealed sire specificity and suggest that there may be a contribution of hereditary factors to the potential fertility of individual bulls, which is in agreement with what can be concluded from the records of insemination results of bulls used in regular A. I. practice.

Rę̧u pour publication en juin 1969.

\section{ACKNOWLEDGEMEN'TS}

The authors are indebted to the assistants C. van Voorst and B. ScheLfHorst, for the skilful organisation and execution of the experimental programme, and the accurate administration and evaluation of the records, respectively.

\section{RÉSUMÉ}

\section{VITESSES SPÉCIFIQUES DE DÉPLACEMEN'T E'T I,ONGÉVITÉ DES SPERMATOZOÏDES DE TAUREAU}

La vitesse moyenne initiale, le nombre de spermatozoïdes normalement mobiles, par unité de volume et la décroissance avec le temps de ces deux valeurs ont été étudiées avec trois paires de vrais jumeaux de la race Frisonne hollandaise.

Au moyen de l'analyse de variance des différences spécifiques entre paires de taureaux ont été observées :

- pour le nombre de spermatozoïdes normalement mobiles par unité de volume $N_{0}$, le taux initial de cléplacement $(N \cdot \bar{v})_{0}$, les paramètres de survie, $t_{1 / 2}(N)$ et $t_{1 / 2}(N \cdot \bar{v})$ et pour les critères de fertilité $t_{1 / 2}(N) \cdot \log N_{0}$ et $t_{1 / 2}(N \cdot \bar{v}) \cdot \log (N \cdot \bar{v})_{0}$.

$-\bar{\partial} \bar{v} / \partial t$

\section{REFERENCES}

DAM G. C. VAN, 1958. Two photometric methods for measurements of bull sperm motility. Tijdschr. Diergeneesk., 83, 1243.

Duijn C. VAN, Jr., 1962. Velocity characteristics and numbers of bull spermatozoa in relation to ageing, determined by photo-electric methods. J. Reprod. Fertil., 4, 277.

DuIJN C. VAN, Jr., I963. Bevruchtend vermogen van spermatozoa in verband met hun beweeglijkheidskenmerken en overlevingsduur. I. Kinetische theorie van de bevruchtingskans. Report No. B 48 of the Research Institute for Animal Husbandry "Schoonoord ", Zeist., 409 pp.

Duijs C. VAN, Jr., I964a. Flet verband tussen aantal, beweeglijkheid en overlevingsduur van spermatozoa en de bevruchtingskans. Ned. Tijdschr. Geneesk., 108, i I 6. 
DUiJn C. VAN, Jr., I964 $b$. Parameters of spermatozoan movement in relation to season, of bulls in the Netherlands. Proc. Vih Internat. Congr. Anim. Reprod., Trento, 6-1 3 sept. I964, Vol. 4, 307.

Duijn C. VAn, Jr., Ig64 c. Kinetics of fertility of semen. Proc. Vth Internat. Congr. Anim. Reprod., Trento, 6-13 sept. I964, Vol. 4, 313.

DUIJN C. VAN, Jr., I964d. A rational method for estimating fertility of spermatozoa in vitro. Proc. Vth Internat. Congr. Anim. Reprod., Trento, 6-13 sept. 1964, Vol. 4, 323.

DuIJN C. VAN, Jr., I $964 e$. The frequency distributions of velocity characteristics and biochemical parameters of bull spermatozoa. Proc. Vth Internat. Congr. Anim. Reprod., Trento, Vol. 4, 355.

DUIJN C. VAN, Jr., I964 f. Relationship between spermatozoan numbers and fertility. Internat. J. Fertil., 9, 609 .

Dujun C. Van, Jr., I965 a. Sperm numbers and fertility : a kinetic approach. Neth. J. Agric. Sci., 13, 378 .

Duijn C. Van, Jr., I965 b. Relations entre les caractéristiques du sperme et la fertilité. Ann. Biol. anim., Bioch., Biophys., 5, 4I9.

Rikmenspoel R., i957a. An optically clear egg-yolk diluent for bull spermatozoa. Experientia, 13, I24.

Rikmenspoel R., $1957 b$. Photoelectric and cinematographic measurements of the "motility " of bull sperm cells. Thesis, Utrecht University. Drukkerij J. H. Smit, Utrecht, Netherlands.

Rikmenspoel R., I960. Measurements of the "motility" of bull sperm cells under various conditions. J. agric. Sci., 54, 399.

Rikmenspoel R., 1962. Biophysical approaches to the measurement of sperm motility. Spermatozoan Motility. Ed. D. W. Bishop. Publ. No. 72 , AAAS, Washington, D. C.

Rikmenspoel R., van Herpen G., van Dam G. C., Eijkhout P., ig6o. Foto-electrisch en cinematografisch onderzoek van de beweeglijkheid van stierenspermatozoa. I. De meetmethodieken. Tijdschr. Diergeneesk., 85, 909-933. 